\title{
Childhood cancer and parental occupation in Finland
}

\author{
K. HEMMINKI, I. SALONIEMI, T. SALONEN, T. PARTANEN, AND H. VAINIO \\ From the Institute of Occupational Health, Helsinki
}

SUMMARY A case-control study was conducted of the occupations of parents of children under 15 with diagnosed malignancies. The total series contained all childhood cancer cases reported to the Finnish Cancer Registry during the period 1959-75. The parental occupations, recorded at the time of pregnancy, were collected from maternity welfare centres. The cases were analysed as a single group or as subgroups according to the diagnoses-brain tumours, leukaemia, and all other malignancies. The maternal occupations found more frequently among cases than controls included farmers' wives (1959-68 only), pharmacists, saleswomen, bakers, and factory work of an unspecified nature (1969-75 only). The paternal risk occupations appeared to be farming, motor vehicle driving, machine repair, painting, and the work of men who gave an academic degree as their occupation. Some of these occupations involve possible exposure to harmful chemicals, although chance correlations cannot be excluded.

Malignancies are one of the main causes of death in childhood at ages 1-14 in developed countries. The incidence of childhood malignancies, particularly of brain tumours, has been increasing over the past 20 years in Scandinavia, probably more than would be expected as a result of changes in diagnostic practice alone. ${ }^{2}$ Epidemiologic studies suggest a number of risk factors for childhood cancer. These include factors associated with the child, with the environment, with the mother during pregnancy, or with the father or the mother before conception. ${ }^{3-6}$

Among the risk factors operating during pregnancy, maternal irradiation has been shown to carry a risk to the child. ${ }^{7-9}$ The maternal intake of diethylstilboestrol has been shown to cause vaginal cancer in the offspring after an intrauterine exposure. ${ }^{10}$ Several types of viral infections have been associated with childhood cancer in the offspring, ${ }^{71} 12$ although negative findings have also been reported..$^{13}$ Prenatal and postnatal exposure to pesticides has also been related to childhood malignancies, but confirmation of these observations is needed. ${ }^{14} 15$

Also, some pre-conception, that is, genetic, risk indicators have been described in the literature. Both maternal and paternal irradiation before conception has been reported to increase the risk that the offspring might contract a malignancy in childhood. ${ }^{16}$ Paternal employment as an anaesthesiologist, ${ }^{17} 18$ or in hydrocarbon- and lead-exposed occupations, ${ }^{19} 20$ has been reported to be associated with childhood malignancies in the offspring, although the analysis of Tomlin has been questioned and the effects of hydrocarbon-exposed occupations have not been confirmed in other studies. ${ }^{21} 22$
The controversial data on the effect of paternal occupation on cancer in the offspring, and, particularly, lack of knowledge on the possible effects of maternal occupation, prompted us to carry out a case-control study. The occupations were recorded during pregnancy and thus the child's subsequent fate could not affect this. The series included all children under 15 diagnosed as having a malignancy in Finland from 1959 to 1975 . Some preliminary results of the analysis have been published ${ }^{2}$ and a part of the material has been analysed for the paternal hydrocarbon-related occupations. ${ }^{21}$

\section{Materials and methods}

Data on children with cancer were obtained from the Finnish Cancer Registry covering all cancer cases diagnosed at ages $<15$. The patients were divided according to ICD VII into three groups: brain tumours (ICD 193); leukaemia (204); and all other

Table 1 Childhood cancer cases in the 1969-75 series by site

\begin{tabular}{lllr}
\hline Primary site & ICD code & No. of patients & $\%$ \\
\hline Leukaemia & 204 & 319 & 33,6 \\
Brain & 193 & 282 & $29 \cdot 7$ \\
Lymphoma & 200,202 & 70 & $7 \cdot 4$ \\
Kidney & 180 & 68 & $7 \cdot 2$ \\
Bone & 196 & 29 & $3 \cdot 1$ \\
Soft tissues & 197 & 28 & $3 \cdot 0$ \\
Eye & 192 & 28 & $3 \cdot 0$ \\
Adrenal gland & 195 & 25 & $2 \cdot 6$ \\
Hodgkin's disease & 201 & 16 & $1 \cdot 7$ \\
Testis & 178 & 15 & $1 \cdot 6$ \\
Skin & $190-191$ & 12 & $1 \cdot 3$ \\
Others & - & 56 & $5 \cdot 9$ \\
& & 948 & $100 \cdot 1$ \\
\hline
\end{tabular}


malignancies. The third group (other tumours) included lymphomas, kidney, bone, eye, soft tissue, and other tumours (Table 1). The information on the parents' occupations was collected from the records of the welfare centres attended by the mothers during pregnancy. The data was collected separately for two periods: $1959-68$ and $1969-75$. For each child with cancer one control child, born next after the case, was selected in the 1959-68 series; in the 1969-75 series two control children, one born next before and one next after the case child, were selected from the same maternity welfare district. If the records of the proper referent were lost, no alternative referent was chosen, and the case was omitted from analysis. Complete information about the occupations of parents of the case and of their matched controls was available in $63 \%$ of the cases in the first series. In the second series (1969-75), complete information about occupations was collected for $87 \%$ of the mothers of the cases and $85 \%$ of the fathers compared with $81 \%$ and $75 \%$ respectively of the mothers and fathers of the controls. The main reasons for the loss of data were loss or destruction of files, ${ }^{23}$ the family moving house, or the arrangement of the files in such a way that the information could not be retrieved since we knew only the name and the birth date of the case child.

A case with complete information on parental occupation was included in the analysis only if the information was available for at least one referent. The total number of pairs with complete information was about 900 for the 1959-68 series and 829 case-mothers, and 1459 referents; and 700 case-fathers and 1182 referents for the 1969-75 series. The childhood cancer cases of 1959-68 have previously been analysed for some variables. ${ }^{21}{ }^{23}$ Detailed information on the $1959-68$ series can be retrieved from these sources.

We coded the parents' occupations based on the records of the maternity welfare centres according to the three-digit classification used by the Central Statistical Office of Finland (1975). This classification can be used to construct main occupational groups (about 10) and detailed occupations (several hundreds), of which 98 were used for women and 145 for men in the present study. The available information did not always allow classification of a person into one of the main occupational categories. 'Women on farms' were farmers' wives taking part in the work to a variable degree, while 'agriculture, gardening and forestry' included women with paid jobs in these occupations. 'Housewives' were women living in non-farming homes. 'Men with academic degree' included men with undefined occupations who had a university degree (this is a common occupational misstatement in Finland). Many men in groups 'technical, scientific, humanistic work' and 'administration and office work' also have academic degrees.

In addition, data were collected on parental ages, mother's obstetric history, and domicile of the child at the time of birth.

In order to assess the comparability of the cases and the referents, several characteristics of the child (for example birthweight) and of the parents (age, parity of mother) were compared and found to be similar in the two groups. Such data for the first series (1959-68) have been published. ${ }^{23}$

The effect of different occupations on the risk of childhood cancer in the offspring was evaluated by calculating the odds ratio, a risk ratio estimate, according to the formulae for matched series with individual ${ }^{24}$ or multiple referents. ${ }^{25} 28$

\section{Results}

The patients included all those with childhood malignancies diagnosed in Finland between 1959-75. The distribution of diagnoses by primary site is listed in Table 1. Leukaemia and brain tumours were the most frequent cancer sites.

\section{MATERNAL OCCUPATION}

The odds ratios for childhood malignancies were calculated according to the maternal occupational groups (Table 2). Two separate periods are shown, 1959-68 and 1969-75, and also the combined series. In only one main group, women living on farms (farmers' wives), a significantly increased $(p<0.05)$ odds ratio was observed for the early but not for the total series. In one subcategory, food industry, a significantly increased odds ratio estimate was also noted for the first and the total series. Among other occupations, commercial and sales workers and also agricultural, gardening, and forestry workers exhibited increased odds ratio estimates $(p<0 \cdot 10)$ in the latter series. Significantly decreased odds ratio estimates were noted for housewives in 1959-68 and in the total series.

Maternal occupations at the time of pregnancy were analysed according to a more detailed job description containing 98 different occupations. The specific occupations with significantly increased odds ratios in the total series are shown in Table 3 according to the type of malignancy diagnosed in the offspring. When the mother was a pharmacist, her children appeared to be more likely to contract any main type of malignancy. The children of saleswomen and bakers appeared more frequently to have tumours other than leukaemia and brain tumours. Another group, in factory work of unspecified nature, showed a high odds ratio estimate 
Table 2 Childhood cancer according to mother's occupational group at the time of pregnancy

\begin{tabular}{|c|c|c|c|c|c|c|}
\hline \multirow[b]{2}{*}{ Occupational group } & \multicolumn{2}{|c|}{$1959-68$} & \multicolumn{2}{|c|}{$1969-75$} & \multicolumn{2}{|c|}{ 1959-75 } \\
\hline & Discordant pairs & Odds ratio & Discordant pairs & Odds ratio & Discordant pairs & Odds ratio \\
\hline $\begin{array}{l}\text { Technical, scientific, humanistic work } \\
\text { Administration, office work } \\
\text { Commercial, sales work } \\
\text { Agriculture, gardening, forestry } \\
\text { Transport, communications } \\
\text { Industrial, construction work } \\
\text { food industry } \\
\text { Service } \\
\text { Women on farms } \\
\text { Housewives } \\
\text { TOTAL }\end{array}$ & $\begin{array}{r}90 \\
79 \\
77 \\
9 \\
20 \\
96 \\
15 \\
69 \\
220 \\
390 \\
1065\end{array}$ & $\begin{array}{l}1.05 \\
1 \cdot 14 \\
1 \cdot 14 \\
0.80 \\
0.82 \\
1 \cdot 18 \\
4 \cdot 00^{*} \\
0.97 \\
1 \cdot 32^{*} \\
0.81^{*}\end{array}$ & $\begin{array}{r}203 \\
168 \\
174 \\
20 \\
32 \\
153 \\
22 \\
146 \\
217 \\
459 \\
1594\end{array}$ & $\begin{array}{l}0.94 \\
0.88 \\
1.26^{\mathrm{a}} \\
2 \cdot 16^{\mathrm{a}} \\
1.52 \\
0.93 \\
1.52 \\
1.06 \\
1 \cdot 00 \\
0.96\end{array}$ & $\begin{array}{r}293 \\
247 \\
251 \\
29 \\
52 \\
249 \\
37 \\
215 \\
437 \\
846 \\
2659\end{array}$ & $\begin{array}{l}0.97 \\
0.96 \\
1.22 \\
1.73 \\
1.19 \\
1.03 \\
2.12^{*} \\
1.03 \\
1.05 \\
0.88^{a}\end{array}$ \\
\hline
\end{tabular}

$a_{p}<0.10 * p<0.05$

Table 3 Maternal occupations with increased odds ratios for malignancies in the offspring in 1959-75

\begin{tabular}{|c|c|c|c|c|c|c|c|c|}
\hline Occupation & $\begin{array}{l}\text { BRAIN TUMOURS } \\
\text { Discordant pairs }\end{array}$ & Odds ratio & $\begin{array}{l}\text { LEUKAEMIA } \\
\text { Discordant pairs }\end{array}$ & Odds ratio & $\begin{array}{l}\text { OTHER TUMOU } \\
\text { Discordant pairs }\end{array}$ & Odds ratio & $\begin{array}{l}\text { ALL MALIGNAN } \\
\text { Discordant pairs }\end{array}$ & $\begin{array}{l}\text { CIES } \\
\text { Odds ratio }\end{array}$ \\
\hline $\begin{array}{l}\text { Pharmacist } \\
\text { Saleswoman } \\
\text { Baker } \\
\text { Factory worker' }\end{array}$ & $\begin{array}{r}2 \\
67 \\
9 \\
5\end{array}$ & $\begin{array}{l}\infty \\
0.95 \\
1.60 \\
8 \cdot 00^{*}\end{array}$ & $\begin{array}{r}5 \\
90 \\
2 \\
5\end{array}$ & $\begin{array}{l}2 \cdot 64 \\
1 \cdot 13 \\
1 \cdot 00 \\
1 \cdot 33\end{array}$ & $\begin{array}{r}5 \\
77 \\
9 \\
5\end{array}$ & $\begin{array}{l}2 \cdot 30 \\
1 \cdot 66^{*} \\
4 \cdot 92^{*} \\
1 \cdot 33\end{array}$ & $\begin{array}{r}12 \\
234 \\
20 \\
15\end{array}$ & $\begin{array}{l}3 \cdot 22^{\circ} \\
1 \cdot 22 \\
2 \cdot 42^{\mathrm{a}} \\
2 \cdot 29^{\mathrm{a}}\end{array}$ \\
\hline
\end{tabular}

$1969-75$ only.

$\mathrm{a} p<0.10 * \mathrm{p}<0.05$

Table 4 Childhood cancer according to father's occupational group

\begin{tabular}{|c|c|c|c|c|c|c|}
\hline \multirow[b]{2}{*}{ Group } & \multicolumn{2}{|c|}{$1959-68$} & \multicolumn{2}{|c|}{ 1969-75 } & \multicolumn{2}{|c|}{ 1959-75 } \\
\hline & Discordant pairs & Odds ratio & Discordant pairs & Odds ratio & Discordant pairs & Odds ratio \\
\hline $\begin{array}{l}\text { Technical, scientific humanistic work } \\
\text { Administration, office work } \\
\text { Commercial, sales work } \\
\text { Agriculture, gardening, forestry } \\
\text { Mining } \\
\text { Transport, communication } \\
\text { Industrial, construction work } \\
\text { Service } \\
\text { Students } \\
\text { Men with academic degree } \\
\text { TOTAL }\end{array}$ & $\begin{array}{r}68 \\
45 \\
42 \\
237 \\
8 \\
160 \\
265 \\
45 \\
34 \\
28 \\
932\end{array}$ & $\begin{array}{l}1 \cdot 34 \\
0.73 \\
0.58^{\mathrm{a}} \\
1 \cdot 42^{* *} \\
3 \cdot 00 \\
1 \cdot 16 \\
0.71^{* *} \\
0.96 \\
1.00 \\
2.11^{\mathrm{a}}\end{array}$ & $\begin{array}{r}193 \\
69 \\
98 \\
242 \\
8 \\
212 \\
403 \\
63 \\
67 \\
33 \\
1388\end{array}$ & $\begin{array}{l}0.89 \\
0.77 \\
1.15 \\
1.05 \\
0.00^{*} \\
1.22 \\
0.96 \\
1.52 \\
0.45^{* *} \\
1.45\end{array}$ & $\begin{array}{r}261 \\
114 \\
140 \\
479 \\
16 \\
372 \\
668 \\
108 \\
101 \\
61 \\
2320\end{array}$ & $\begin{array}{l}1 \cdot 00 \\
0 \cdot 75 \\
0 \cdot 89 \\
1 \cdot 19 \\
0 \cdot 84 \\
1 \cdot 18 \\
0 \cdot 85^{*} \\
1 \cdot 25 \\
1 \cdot 13 \\
1 \cdot 71^{*}\end{array}$ \\
\hline
\end{tabular}

$a_{p}<0.10 * p<0.05 * * p<0.01$

for brain tumours, but the significant increase was found only in the later series (1969-75).

PATERNAL OCCUPATION

Paternal occupations were analysed as shown in Table 4. An increased odds ratio was observed for the agricultural, gardening, and forestry workers' children and for the children of men giving only an academic degree as their occupation. In both cases the risk appeared to be more marked in the earlier (1959-68) series. Significantly decreased odds ratio estimates were observed for the miners' and the students' children in the later series, and for the industrial and construction workers' children in the early and the combined series.

The detailed occupations with a significant increase in the odds ratio for malignancies in the offspring are shown in Table 5. A total of 145 occupations were analysed. The farmers' children appeared likely to contract any type of malignancy. The motor vehicle drivers' children were likely to contract leukaemia, and the risk appeared to be more marked in the later series. The offspring of the machine repair men and of the painters appeared to be prone to brain tumours. The odds ratios for painters were higher in the later than in the total series.

\section{Discussion}

The present study covered all childhood malignancies diagnosed in Finland between 1959 and 1975. One weakness of the study was that only occupational information could be collected from the 
Table 5 Paternal occupations with increased odds ratios for malignancies in the offspring in 1959-75

\begin{tabular}{|c|c|c|c|c|c|c|c|c|}
\hline \multirow[b]{2}{*}{ Occupation } & \multicolumn{2}{|c|}{ BRAIN TUMOURS } & \multirow{2}{*}{$\begin{array}{l}\text { LEUKAEMIA } \\
\text { Discordant pairs }\end{array}$} & \multirow[b]{2}{*}{ Odds ratio } & \multicolumn{2}{|c|}{ OTHER TUMOURS } & \multicolumn{2}{|c|}{ ALL MALIGNANCIES } \\
\hline & Discordant pairs & Odds ratio & & & Discordant pairs & Odds ratio & Discordant pairs & Odds ratio \\
\hline Farmers & 107 & $1 \cdot 15$ & 1.56 & $1 \cdot 26$ & 187 & 1.22 & 450 & $1 \cdot 22^{*}$ \\
\hline $\begin{array}{l}\text { Motor vehicle } \\
\text { drivers } \\
\text { Motor vehicle }\end{array}$ & 84 & 0.92 & 96 & $1.50^{\mathrm{a}}$ & 123 & 1.33 & 303 & $1.25^{\mathrm{a}}$ \\
\hline $\begin{array}{l}\text { drivers }{ }^{1} \\
\text { Machine repair }\end{array}$ & 57 & 1.07 & 45 & $1 \cdot 90^{*}$ & 71 & $1 \cdot 31$ & 173 & 1.36 \\
\hline $\begin{array}{c}\text { men } \\
\text { Painters }\end{array}$ & $\begin{array}{l}14 \\
14\end{array}$ & $\begin{array}{l}4 \cdot 39^{*} \\
2 \cdot 59^{\mathrm{a}}\end{array}$ & $\begin{array}{l}15 \\
12\end{array}$ & $\begin{array}{l}0.25^{*} \\
1.50\end{array}$ & $\begin{array}{l}17 \\
14\end{array}$ & $\begin{array}{l}0.54 \\
0.70\end{array}$ & $\begin{array}{l}46 \\
40\end{array}$ & $\begin{array}{l}0.89 \\
1.39\end{array}$ \\
\hline Painters ${ }^{1}$ & 7 & $5 \cdot 00^{*}$ & 7 & 2.67 & 5 & 1.33 & 21 & $2 \cdot 75^{*}$ \\
\hline
\end{tabular}

$1969-75$ only.

$\mathrm{p}<0.10 * \mathrm{p}<0.05$

parents: details of exposure were not available. The occupational groups contain heterogeneous subgroups with mixed exposures. Data on chemical and physical exposure would have been more pertinent for the identification of aetiological factors. The collection of reliable information on exposure from the parent in relation to malignancies in the offspring is, however, exceedingly difficult and subject to bias. Another weakness of the study was our inability to collect occupational information on all cases and referents. This was particularly true of the early series (1959-68). Yet it should be emphasised that in a large proportion of the cases the information was lacking because the records were destroyed, lost, or organised in a way that made it impossible for us to use them, reasons not likely to correlate with occupation of the parents. In a few cases the records were lost because the family had moved and their maternity welfare centre records had disappeared. As such losses may correlate with occupation, they could cause some bias to the results. However, as explained in the methods section, loss of data on the proper referent resulted in the omission of the case from the analysis to avoid bias. No alternative control was chosen.

As far as we know, the present study is the first attempt to investigate the role of maternal occupation at the time of pregnancy in relation to childhood malignancies in the offspring. In view of the established risk factors such as irradiation ${ }^{7-9}$ and diethylstilboestrol, ${ }^{10}$ the investigation appears warranted. Furthermore, ample experimental evidence has been provided for transplacental carcinogenesis. ${ }^{27}{ }^{28}$

The farmers' wives were the only main occupational group in which a significantly increased odds ratio estimate was detected. The increase was found only in the first series (1959-68); thus, if some risk factors were present earlier, they had probably disappeared over the years. The disappearance of the apparent risk was confirmed by analysing the data according to the year of birth. As expected, the results for farmers were similar to those for farmers' wives. In one subcategory, food industry, an increased odds ratio was also detected. The increase was mainly due to the bakers' children, who were likely to contract a malignancy other than brain tumour or leukaemia. The exact types of tumour were investigated but they were found to be heterogeneous. The other specific maternal occupations for which increased odds ratios were detected were pharmacists, saleswomen and, in the latter series only, factory work of unspecified nature. Harmful chemical factors are likely to be present in pharmacies and factories, but as yet there is no information about possible carcinogenic exposure affecting saleswomen and bakers. About 100 occupations were analysed, so chance correlations are likely to be present. The possibility of risk can be assessed only from other studies and from considerations of biological plausibility.

In addition to farmers, discussed above, the paternal risk occupations appeared to be for men giving an academic degree as their occupation, motor vehicle drivers, machine repair men, and painters; the last three were particularly pronounced in the 1969-75 series. There is no clear explanation of why the men giving an academic degree as their occupation would be at risk, particularly as the main occupational groups 'technical, scientific and humanistic work' and 'administration, office work' also contain many men with academic degrees and no risks were noted for these groups. Yet the British study $^{22}$ also reported high proportionate mortality ratios for the children of the professional classes. Leukaemia appeared to be particularly common among children of motor vehicle drivers who were themselves also reported to be at risk of leukaemia. ${ }^{29}$ Petrol is known to contain carcinogenic compounds such as benzene (leukaemogen), dichloroethane and dibromoethane. The children of machine repair men and painters appeared to be at particular risk of brain tumours. The two occupational groups are exposed to a number of chemical factors such as chromium and various solvents. The present results are in partial agreement with those of Fabia and Thuy ${ }^{19}$ 
which reported high rates for children of painters ('painters, dyers, cleaners') and machinists ('machinists, miners and lumbermen'), whereas no risk was suggested for drivers' children.

In the present study, based on two separate series of childhood cancer cases, we noted some parental occupations which were more common among the case-parents than among the referent-parents. In some maternal occupations (pharmacists, factory workers) and paternal occupations (motor vehicle drivers, machine repair men, painters), harmful chemical exposure is known to occur. Even though such findings could be biologically plausible, there is no way to exclude chance correlations. Thus studies from other countries are needed to examine this important problem further.

We thank Dr. Härö and Ms. A. Ruusinen of the National Board of Medicine and Ms. P. Fahlström, Ms. I. Hannunkari, and Mr. R. Kuronen. The childhood cancer cases were identified and supplied to us by the Finnish Cancer Registry.

Reprints from Dr. K. Hemminki, Department of Industrial Hygiene and Toxicology, Institute of Occupational Health, Haartmaninkatu 1, SF 00290, Helsinki 29, Finland.

\section{References}

${ }^{1}$ Ericsson JL.-E, Karnström L, Mattson B. Childhood cancer in Sweden, 1958-1974. I. Incidence and mortality. Acta Paediatr Scand 1978; 67: 425-32.

${ }^{2}$ Hemminki K, Saloniemi I, Luoma K, Salonen T, Partanen T, Vainio H, Hemminki E. Transplacental carcinogens and mutagens: childhood cancer, malformations and abortions as risk indicators. $J$ Toxicol Environ Health 1980; 6: 1115-24.

${ }^{3}$ Miller RW. Aetiology of childhood cancer: epidemiological approach. In: Tumours in Children, 2nd edn. Marsden HB, Steward JK, ed. Berlin: Springer-Verlag, 1976: 14-27.

${ }^{4}$ Munoz N. Prenatal exposure and carcinogenesis. Tumori 1976; 62: 157-62.

${ }^{5}$ Draper GJ. Epidemiological studies and the genetic component in the aetiology of childhood cancers. In: Tumours of early life in man and animals. Severi L, ed. Perugia: Quadrennial International Conference on Cancer, 1978: 10-113.

${ }^{6}$ Hemminki K. Sorsa M. Vainio H. Genetic risks caused by occupational chemicals. Scand J Work Environ Health 1979; 5: 307-27.

${ }^{7}$ Stewart A, Webb J, Hewitt D. A survey of childhood malignancies. $\mathrm{Br}$ Med J 1958; i: 1495-1508.
${ }^{8}$ MacMahon B. Prenatal X-ray exposure and childhood cancer. J Natl Cancer Inst 1962; 28: 1173-91.

${ }^{9}$ Stewart A, Kneale GW. Radiation dose effects in relation to obstetric X-rays and childhood cancers. Lancet 1970; i: $1185-7$.

${ }^{10}$ Herbst AL, Ulfelder H. Poskanzer DC. Andenocarcinoma of the vagina. $N$ Engl J Med 1971; 284: 878-81.

${ }^{11}$ Adelstein AM, Donovan JW. Malignant disease in children whose mothers had chickenpox, mumps or rubella in pregnancy. $\mathrm{Br}$. Med $J$ 1972; iv: 629-31.

${ }^{12}$ Fredrick J, Alberman ED. Reported influenza in pregnancy and subsequent cancer in the child. $\mathrm{Br} M e d \mathrm{~J}$ 1972; ii: $485-8$.

${ }^{13}$ Leck I, Steward JK. Incidence of neoplasms in children born after influenza epidemics. $\mathrm{Br}$ Med $J$ 1972; iv: 631-4.

${ }^{14}$ Infante PF, Epstein SS, Newton WA. Blood dyscrasias and childhood tumors and exposure to chlordane and heptachlor. Scand J Work Environ Health 1978; 4: 137-50.

${ }^{15}$ Gold E, Gordis L, Tonascia J, Szki M. Risk factors for brain tumors in children. Am J Epidemiol 1979; 109: 309-11.

${ }^{16}$ Graham S, Levin ML, Lilienfeld AM, Scuman LM, Gibson R, Dowd JE, Hempelmann L. Preconception, intrauterine and postnatal irradiation as related to leukemia. National Cancer Institute Monograph 1966; 19: 347-71.

${ }^{17}$ Corbett TH, Cornell RG, Enders JL, Lieding K. Birth defects among children of nurse anesthetists. Anesthesiology 1974; 41: 341-4.

${ }^{18}$ Tomlin PJ. Health problems of anaesthetists and their families in the West Midlands. $\mathrm{Br} M e d J 1979$; i: 779-84.

${ }^{19}$ Fabia J, Dan Thuy T. Occupation of father at time of birth of children dying of malignant disease. Br J Prev Soc Med 1974; 28: 98-100.

${ }^{20}$ Kantor AF, McGrea Gurnen MG, Wister Meigs J, Flannery JT. Occupations of fathers of patients with Wilms's tumour. J Epidemiol Community Health 1979; 33: 253-6.

${ }^{21}$ Hakulinen T, Salonen T, Teppo L. Cancer in the offspring of fathers in hydrocarbon-related occupations. $\mathrm{Br} \mathrm{J} \mathrm{Prev}$ Soc Med 1976; 30: 138-140.

${ }^{22}$ Sanders BM. Childhood cancer and occupation of father. Personal communication, 1979.

${ }^{23}$ Salonen T, Saxén L. Risk indicators in childhood malignancies. Int J Cancer 1975; 15: 941-6.

${ }^{24}$ Miettinen OS, Estimation of relative risk from individually matched series. Biometrics 1970; 26: 75-86.

${ }^{25}$ Miettinen OS. Principles of epidemiologic research. Harvard: Department of Epidemiology and Biostatistics, School of Public Health, Harvard University, 1975: Unpublished course text.

${ }^{26}$ Rothman KJ, Boice JD Jr. Epidemiologic analysis with a programmable calculator. Washington DC: US Government Printing Office, 1979.

${ }^{27}$ Rice JM. Perinatal period and pregnancy: intervals of high risk for chemical carcinogens. Environ Health Perspect 1979; 29: 23-8.

${ }^{28}$ International Agency for Research on Cancer. Transplacental carcinogenesis. Lyon: IARC. 1973: 181.

${ }^{29}$ Sauli H. Occupational mortality in 1971-75. Helsinki: Central Statistical Office of Finland, 1979. 